\title{
Online public relations: What are the mechanisms that should be used by practitioners to elevate their performance?
}

\author{
Rasha Adel Alyaqoub \\ University Utara Malaysia \\ rashaalyaqoub@yahoo.com
}

\begin{tabular}{ll}
\hline ARTICLEDETAILS \\
\hline History & \\
Received & $:$ February \\
RevisedFormat & : March \\
Accepted $\quad:$ April \\
\hline
\end{tabular}

\section{Keywords :}

online PR, PR practitioners, mechanisms, performance, new technologies.

\begin{abstract}
S
Despite the elevated interest in new technologies in the public relations practice, their use is still achieved in a random, traditional, disorganized way and without a particular strategy or methodology. This randomness in non-use may be caused by the lack of conviction of the role of modern technological tools and their importance to activate the dialogue between the organization and its audience. In addition to enabling them to achieve their objects such as promotion, building a strong reputation and increase loyalty and thus increase sales or services provided. The other reason is that this area is still considered relatively new. Literature still lacks studies that show the mechanisms that practitioners should follow to improve and develop their performance, although many studies have shown that there are many gaps and issues in the online PR practice, such as weaknesses in technological skills, weakness in the concept of online pr. Studies have also found factors that affect on the non-use of these tools or use them in an abusive manner. Therefore, there is a need for studies to show the mechanisms of dealing with these tools effectively. This study attempted to explore the literature in this field and found several mechanisms that could be used to improve and develop the practice of online PR.
\end{abstract}

\section{INTRODUCTION}

Public relations (PR) plays a vital role in any organization by supporting an organization's activities while reinforcing its image. In addition, it communicates with external publics such as customers and shareholders. Ahmad and Ismail (2015) believed that PR aspires to maintain a mutually beneficial and long-term relationship between a concern and its key publics by balancing the interests of each party. PR often encompasses creating and maintaining a positive image and is aimed at providing consistent and constant communication with an organization's various stakeholders (Ahmad \& Ismail, 2015).

Modern PR can be considered from several perspectives. The first PR may be considered as the art of dealing with the public in all its forms and using various tools suitable for reaching various audiences. Second, as Kowalski (2004) pointed out PR is also a science, although PR has not yet achieved the status as more established professions such as law or medicine, that require specific education and licensing. Lastly, "public relations are the management function that establishes and maintains mutually beneficial relationships between an organization and the publics on whom its success or failure depends" (Cutlip, Center, \& Broom, 2000, p. 6).

In managing these relationships, modern PR practitioners utilize scientific methods to make their efforts more efficient and effective. Indeed, the PR Society of American notes that modern PR comprises a four-step process with functions including research, strategizing and planning implementation, and evaluation (PRSA, n.d.). In managing their programs, PR 
specialists have access to an increasing body of literature and theory that could be used to guide practices .

PR today can utilize ICT to spread messages quickly, and PR practitioners can manage various Internet sites with all their strengths and weaknesses (Vosoghpour \& Jafari, 2016). This means that the profession of PR intervenes in all aspects of life and works to influence target audiences to achieve its goals.

Indeed, PR can now communicate with people in simple and straightforward ways especially through various means of information technology, which have brought dramatic changes in the field of information dissemination including the emergence of social network, new media and advanced software production blogs, and other ways of using ICT in PR.

PR scholars have conducted studies about online PR in organizations, in general, to know about why and how and what are the gaps that affect to use these tools. And they found that PR practitioners often utilize these modern technological tools simplistically and modestly without a particular strategy. Like Grunig (2009) who said that "PR practitioners, doggedly use the new media in the same way that they used traditional media"(p.8). Beside that PR scholars found that there are several gaps in the online PR practice. such as there is a misunderstanding in the concept of online PR among the practitioners (Bhargava ,2010; Fitch ,2009; Inya ,2017; Kent \& Suffer, 2014; Liptak ,2012; Robson \& James ,2013; Toledano \& Avidar ,2016).

Other studies have found that the acceptance of the online PR practice concept is related to authoritarian decision-making and a lack of education and skills (Al-Shohaib, Kandari, \& Abdulrahim, 2009; Al-Shohaib, Frederick, Jamal Al-Kandari, \& Dorsher, 2010; Ayish, 2005; Bashir \& Aldaihani, 2017; James, 2007; Fitch, 2009; Kirat, 2005, 2006, 2007, 2016; Robson \& James, 2013; Vardeman-Winter \& Place, 2015).

In addition to that, many researchers believed that PR practitioners do not have technical skills that enable them to use social media. Such absence of skills can be a barrier to those practitioners and can result in an unwillingness to use social media (Bashir \& Aldaihani, 2017). In addition to the many issues and gaps found in the practices of online PR through the literature. Therefore, proposing specific mechanisms to develop an understanding of how to achieve online PR objectives fully is necessary .

\section{THE MECHANISMS}

Indeed, many studies have recommended conducting additional research to find mechanisms to learn more about the effectiveness of these tools and understand how the advantage of these tools can be increased. For example, Al-Shohaib, Frederick, Jamal AlKandari and Dorsher (2010) explored factors influencing the adoption of the Internet by PR professionals in private and public sectors of Saudi Arabia and found that managers must understand the different organizational cultures operating within a single national culture.

Furthermore, Veletsianos, Kimmons, Shaw, Pasquini and Woodward (2017) urged that institutional leaders and offices managing social media accounts should reflect on how and why they use these technologies. For example, although the large following that social media can garner accounts could assist institutions in performing knowledge-sharing, knowledge-building, and educative functions, such activities are constrained at present by limiting the utilization of these technologies to broadcasting and promoting. Indeed, Alikilic and Atabek (2012) suggested that integrating social media into the curriculum of higher education PR programs to build a better understanding of these tools is critical. Campbell, Lambright and Wells (2014) recommended increasing the awareness of the value of social media and that scholars should share their research with leaders of public and non-profit organizations on how social media can be used not just for one-way communication but also to engage stakeholders in interactive dialogues. 
Gordon (2010) said that "because social media are viewed as untrustworthy, inaccurate and not credible" (p. 45), more research should be conducted both on those using these new media outlets, especially those who publish blogs and on how to raise credibility. Because of the controversial nature of this topic, one recommendation is for a credible organization to create and promulgate a bloggers code of ethics. Also, Sebastião, Zulato and Santos (2017) said PR practitioners require more training in ethics. Perhaps more dialogue with academia is required to define essentials and guidelines in the field of ethics. Furthermore, to elicit ethical principles and guidelines from the several extant codes of ethics and conduct, explanations and examples of ethical and unethical practices must be given. Thus, ethics must go beyond mere philosophical and moral statements and become an applied instrument to become effective. More, clients must be drawn into consideration of these concerns.

Zebrass and Schramm (2014) concluded that newsrooms should be developed that utilize the full power of social media platforms in terms of information, identity and relationship management. Social Media Newsrooms offer a full range of opportunities for PR. However, as in many other fields, this needs strategic thinking and creative power to create its potential and productivity in corporate practices.

In the same context, some scholars have confirmed that changes in policy and government communication systems are vital for enhancing PR practice among PR practitioners. For example, Park (2016) said that the new PR environment requires changing government communication systems to accept the opening and sharing of data or information and public participation in decision-making with privacy protections while providing useful content, credibility and security.

Another scholar suggested that creating a written monthly plan for social media accounts is important. The planned posts should keep in mind holidays, cover any business and community events, and incorporate information that their audience might find to be applicable (Kreun, 2016).

Moreover, Inya (2017) found that the contents of social media platforms of universities should be generated and shared daily. PR managers in a university should prioritize using social media to enhance the global ranking of their universities. Therefore, managers should mandate that every staff of their public relations unit and ICT create a blog or Facebook and Twitter accounts with hyperlinks to their institution's website. This will help in generating the backlinks needed to improve the Webometric ranking of their universities. Bashir and Aldaihani (2017) suggested improving PR education by including more technical skills that practitioners should acquire and applying PR theories and models can also enhance the understanding of how social media can be used for organizational communication and how they can be effectively used with publics. Also, Shahid, Akram, Zulqarnain and Hashmi (2018) pointed out that PR practitioners can develop themselves through beginning to take risks with things that have already shown to be successful such as social media campaigns. Institutions can improve their use of social media and more knowledge, and better practices can be implemented into their routines.

Grunig (2009) believe that" PR cannot take full advantage of the digital revolution if it is practised under the interpretive rather than the strategic management paradigm"(p.8). Furthermore, Grunig (2009) found a model for strategic PR and gives recommendations for the usage of digital media in each phase of this model. These recommendations as a mechanism to use digital tools for PR to improve online PR practice. Which are: use Communication programs, Environmental scanning, Segmenting stakeholders and publics, Anticipating and dealing with issues and crises, Measuring relationships and reputation and Evaluation of communication programs.

Other studies ascertained that PR practitioners are required to acquire skills to raise their performance. Most studies have emphasised that if practitioners have acquired and enhanced their e-skills, they will be able to utilise internet applications effectively. These skills like 
online security, publishing on the web, operation of new software, web analytics, optimization of search engine and web trend analysis software operation (Nowland, 2006).In addition to ICT skills (Breakenridge, 2012; Kirat 2005; 2006;2016; Sha, 2011; Wilcox, Cameron, Reber \& Shin ,2013).

Table 1

shows the suggestions of researchers to increase the performance levels of practitioners and $P R$ departments through online $P R$.

\begin{tabular}{|c|c|}
\hline Mechanisms & Scholar(s) /year \\
\hline $\begin{array}{l}\text {-Understand the different organizational } \\
\text { cultures operating within a single national } \\
\text { culture. }\end{array}$ & $\begin{array}{l}\text { Al-Shohaib, Frederick, Jamal Al-Kandari } \\
\text { and Dorsher (2010) }\end{array}$ \\
\hline $\begin{array}{l}\text {-Institutional leaders and offices managing } \\
\text { social media accounts to reflect on how and } \\
\text { why they use these technologies. } \\
\text {-The large following garnered by social } \\
\text { media accounts can assist institutions in } \\
\text { performing knowledge-sharing, knowledge- } \\
\text { building, and educative functions. }\end{array}$ & $\begin{array}{l}\text { Veletsianos, Kimmons, Shaw, Pasquini and } \\
\text { Woodward, (2017) }\end{array}$ \\
\hline $\begin{array}{l}\text {-Integration of social media to the } \\
\text { curriculum of higher education PR } \\
\text { programs to building a better understanding } \\
\text { of these tools. }\end{array}$ & Alikilic and Atabek (2012) \\
\hline $\begin{array}{l}\text {-Increase awareness of social media's } \\
\text { potential value. } \\
\text {-scholars should share their research with } \\
\text { others. }\end{array}$ & Campbell, Lambright and Wells (2014) \\
\hline $\begin{array}{l}\text {-more research should be conducted both on } \\
\text { those using these new media outlets and on } \\
\text { how to raise credibility. } \\
\text {-create and promulgate a bloggers code of } \\
\text { ethics. }\end{array}$ & Gordon (2010) \\
\hline $\begin{array}{l}\text {-PR practitioners need more training in } \\
\text { matters of ethics. }\end{array}$ & Sebastião, Zulato and Santos (2017) \\
\hline $\begin{array}{l}\text {-Develop newsrooms that utilize the full } \\
\text { power of such platforms in terms of } \\
\text { information, identity and relationship } \\
\text { management. }\end{array}$ & Zerfass and Schramm (2014) \\
\hline $\begin{array}{l}\text {-Change the policy and government } \\
\text { communication system. }\end{array}$ & Park (2016) \\
\hline $\begin{array}{l}\text {-Create a written monthly plan for social } \\
\text { media accounts. }\end{array}$ & Kreun (2016) \\
\hline $\begin{array}{l}\text {-The Contents on the social media platforms } \\
\text { of the universities should be generated and } \\
\text { shared daily. } \\
\text {-PR managers in the university should } \\
\text { prioritize using social media to enhance the } \\
\text { global ranking of their universities. }\end{array}$ & Inya (2017) \\
\hline $\begin{array}{l}\text {-Improvement in PR education by including } \\
\text { more technical skills that practitioners } \\
\text { should acquire and be willing to acquire } \\
\text { applying PR theories and models }\end{array}$ & Bashir and Aldaihani (2017) \\
\hline $\begin{array}{l}\text {-PR practitioners can develop themselves } \\
\text { through beginning to take risks with things } \\
\text { that have already shown to be successful, } \\
\text { such as social media campaigns. }\end{array}$ & $\begin{array}{l}\text { Shahid, Akram, Zulqarnain \& Hashmi } \\
\text { (2018) }\end{array}$ \\
\hline
\end{tabular}




\begin{tabular}{l|l}
\hline -Communication programs. & Grunig (2009) \\
- Environmental scanning. & \\
-Segmenting stakeholders and publics. & \\
-Anticipating and dealing with issues and & \\
crises. & \\
-Measuring relationships and reputation and & \\
Evaluation of communication programs. & \\
\hline & \\
\hline
\end{tabular}

Source: based on the researcher

\section{CONCLUSION}

It has become clear that public relations at today cannot work in isolation from the internet and modern technology. Especially that the Internet and technological tools are utilised by most of the world population, especially young people, who are among the most important target groups by companies and organizations. Because the usage of technology in the field of public relations is still new, this use is still random and unstructured, which led to the emergence of gaps in this practice, so this study tried to discover some mechanisms that could help improve the online PR practice among the practitioners. The study also recommends conducting further research to explore more mechanisms that regulate online PR practice.

\section{REFERENCES}

Ahmad, J. H., \& Ismail, T. A. (2015). Public relations vs. advertising. Jurnal Komunikasi, Malaysian Journal of Communication, 31(2).

Alikilic, O., \& Atabek, U. (2012). Social media adoption among Turkish public relations professionals: A survey of practitioners. Public Relations Review, 38(1), 56-63.

Al-Shohaib, K., Al-Kandari, A. A., \& Abdulrahim, M. A. (2009). Internet adoption by Saudi public relations professionals. Journal of Communication Management, 13(1), 21-36.

Al-Shohaib, K., Frederick, E., Jamal Al-Kandari, A. A., \& Dorsher, M. D. (2010). Factors influencing the adoption of the internet by public relations professionals in the private and public sectors of Saudi Arabia. Management Communication Quarterly, 24(1), 104-121.

Bashir, M., \& Aldaihani, A. (2017). Public relations in an online environment: Discourse description of social media in Kuwaiti organizations. Public Relations Review, 43(4), 777-787.

Bhargava, D. (2010). The use of Internet in public relations and its impact on the practice: A New Zealand perspective (Doctoral dissertation, Auckland University of Technology).

Breakenridge, D. (2012). Evaluating employer communication competency expectations: A pilot study. PR 2.0 Strategies.

Campbell, D. A., Lambright, K. T., \& Wells, C. J. (2014). Looking for friends, fans, and followers? Social media use in public and nonprofit human services. Public Administration Review, 74(5), 655-663.

Cutlip, D.A., Center, A.H., \&Broom, GM. (1999). Effective Public Relation. New jersey: Prenticr-Hall.Inc.

Fitch, K. (2009). The new frontier: Singaporean and Malaysian public relations practitioners' perceptions of new media. Asia Pacific Public Relations Journal, 10, 17-33.

Gordon, J. (2010). Use, Value and Impact of Social Media on Public Relations Practitioners in the Fox Cities (Unpublished doctoral dissertation). University of Wisconsin Oshkosh).

Grunig, J. E. (2009). Paradigms of global public relations in an age of digitalisation. PRism, 6(2), 1-19.

Inya, A. E. (2017). Influence of Social Media on Public Relations Practices in Universities in South-East, Nigeria. Global Journal of Human-Social Science Research. 
James, M. (2007). A review of the impact of new media on public relations: Challenges for terrain, practice and education. Asia Pacific Public Relations Journal, 8(1), 137-148.

Kent, M. L., \& Saffer, A. J. (2014). A Delphi study of the future of new technology research in public relations. Public Relations Review, 40(3), 568-576.

Kirat, M. (2005). Public relations practice in the Arab World: A critical assessment. Public Relations Review, 31(3), 323-332.

Kirat, M. (2006). Public relations in the United Arab Emirates: The emergence of a profession. Public Relations Review, 32(3), 254-260.

Kirat, M. (2007). Promoting online media relations: Public relations departments' use of Internet in the UAE. Public Relations Review, 33(2), 166-174.

Kirat, M. (2015). The Islamic roots of modern public relations and corporate social responsibility. International Journal of Islamic Marketing and Branding, 1(1), 97112.

kirat, M.(2016). Public Relations Professionalism and Excellence in the Arab World Problems and Drawbacks. Retrieved from https://www.researchgate.net/publication/308414690_Public_Relations_Professional ism and Excellence in the Arab World Mohamed Kirat Public Relations Profe ssionalism_and_Excellence_in_the_Arab_World_Problems_and_Drawbacks.

Kowalski, T. J. (2004). The ongoing war for the soul of school administration.

Kreun, A. J. (2016). An analysis of how public relations professionals use social media.

Liptak, M. (2012). Diffusion of social media among public relations practitioners (Doctoral dissertation, Quinnipiac University).

Nowland, P. (2006). PR Trends: A press release for social media. Entrepreneur.com. Retrieved from https://www.entrepreneur.com/article/170552

Park, S. H. (2016). On the Effectiveness of Social media for the Public Relations of Korean Government Ministries. Indian Journal of Science and Technology, 9(46).

PRSA. (n.d.). Public relations: A management function. Retrieved from http://www.praccreditation.org/resources/documents/APRSG-PR-Mgmt-

Function.pdf

Robson, P. (2013). Time to bridge the gaps: issues with current social media research in public relations. Australian and New Zealand Communication Association Conference (ANZCA 2013), Freemantle, Western Australia. http://hdl. handle. net/1959.13/1052721.

Robson, P., \& James, M. (2013). Not everyone's aboard the online public relations train: the use (and non-use) of social media by public relations practitioners.

Sebastião, S. P., Zulato, G., \& Santos, T. B. (2017). Public relations practitioners' attitudes towards the ethical use of social media in Portuguese speaking countries. Public Relations Review, 43(3), 537-546.

Sha, B. L. (2011). Does accreditation really matter in public relations practice? How age and experience compare to accreditation. Public Relations Review, 37(1), 1-11.

Shahid, K., Akram, E., Zulqarnain, W., \& Hashmi, N. U. (2018, August). Reshaping Public Relation through Social Media: A Study on Influence and Challenges in Universities. In Indonesia International Graduate Conference on Communication (IndoIGCC) Proceeding (Vol. 2, pp. 740-752).

Toledano, M., \& Avidar, R. (2016). Public relations, ethics, and social media: A crossnational study of PR practitioners. Public Relations Review, 42(1), 161-169.

Vardeman-Winter, J., \& Place, K. (2015). Public relations culture, social media, and regulation. Journal of Communication Management, 19(4), 335-353.

Veletsianos, G., Kimmons, R., Shaw, A., Pasquini, L., \& Woodward, S. (2017). Selective openness, branding, broadcasting, and promotion: Twitter use in Canada's public universities. Educational Media International, 1-19.

Vosoghpour, F., \& Jafari, A. (2016). The role of new information and communication technologies in the performance of public relations (case study: electronic payment card network shaparak). Turkish online journal of design art and communication, 6,95-101.

Wilcox, D. L., Cameron, G. T., Reber, B. H., \& Shin, J. H. (2013). Think public relations. Pearson Higher Ed. 